\title{
What Social Workers Should Know About Ethics: Understanding and Resolving Practice Dilemmas
}

\author{
Elaine P. Congress
}

\begin{abstract}
Recognizing ethical issues and dilemmas that arise in professional practice is crucial for social work practitioners, educators, and students. After a discussion about the limited, although growing, literature on social work ethics, the ten main tenets from the most current NASW Cade of Ethics are presented. These topics include limits to confidentiality, confidentiality and technology, confidentiality in family and group work, managed care, cultural competence, dual relationships, sexual relationships, impairment and incompetence of colleagues, application to administrators and relevance to social work educators. In addition to understanding the Code of Ethics, social workers can use the ETHIC model of decision making for resolving ethical dilemmas. This easy to use five step process includes examining personal, agency, client, and professional values, thinking about ethical standards and relevant laws, hypothesizing about consequences, identifying the most vulnerable, and consulting with supervisors and colleagues. A case example involving confidentiality, HIV/AIDS, and family therapy demonstrates how social workers can use the ETHIC model.
\end{abstract}

While the social work profession has always been value-based and ethical practice has long been an educational concern (Pumphrey, 1959), within the last twenty years there has been increasing interest in this topic (Reamer, 1995b). Over the years the ethical focus has shifted from a focus on the morality of the client to the ethical behavior of the practitioner (Reamer, 1995b) and most recently to social work educators (NASW, 1996).

The NASW Code of Ethics provides a standard for ethical practice for social work practitioners and educators. This chapter has two objectives 1. a discussion of what is new about the current Code of Ethics and 2. a proposed model for ethical decision making (ETHIC) that is easy to apply to complex ethical dilemmas. The goal is to improve ethical practice and decision making among practitioners and educators.

Elaine Congress, DSW, is professor and director of the Ph.D. Program, Graduate School of Social Service Fordham University. 


\section{ETHICS AND PRACTICE}

The social work value and ethical base for the profession has been reaffirmed in the centennial year of our profession (Reamer, 1998). In addition to generic texts on social work ethics (Lowenberg \& Dolgoff, 1996; Reamer, 1995b; Rhodes, 1991), a review of Social Work Abstracts for the last decade lists thirty-one (31) professional journal articles on social work values and ethics. Many of these articles have focused on ethical concerns in health care (Abramson, 1990; Beauchamp \& Childress, 1994; Callahan, 1994; Congress and Lyons, 1992; Fandetti and Goldmeier, 1988; Joseph and Conrad, 1989; Proctor, Morrow-Howell \& Lott, 1993; Roberts, 1989). Other literature relates to different fields of practice including HIV/AIDS (Abramson, 1990), child welfare (Pine, 1987), and school social work (Berman-Rossi \& Rossi, 1990; Congress \& Lynn, 1994; Garrett, 1994). With the increase in malpractice litigation, more literature has focused on liability and malpractice issues (Houston-Vega, Nuehring, Dagio, 1997; Reamer, 1994). Controversial Ethical Issues in Social Work Practice (Gambrill and Pruger, 1996) considers ethical debates in social work practice, while two of the most recent books on social work ethics have focused on the new Code of Ethics (Congress, 1999a; Reamer, 1998).

\section{CODE OF ETHICS}

The first Code of Ethics for the National Association of Social Workers contained fourteen abstract statements listed on one page (NASW, 1960). The Code was revised and expanded in 1967, 1979, 1990, 1993, and 1996. Previous codes had been critiqued as not stressing professional standards (Jayaratne, Croxton, \& Mattison, 1997). Although the previous code can be applied to social work educators (Lewis, 1987; Congress, 1992) and administrators (Congress, 1996), there were not specific sections referring to administrators (Congress \& Gummer, 1996) and educators (Congress, 1992). Another concern was that the code spoke primarily about individual treatment concerns, rather than group work (Dolgoff and Skolnick, 1992). The current 27-page Code addresses many of these issues. Professional standards are presented, as well as sections on educators, administrators, and group workers (NASW, 1996). Included in the code is a description of core values, as well as ethical standards. While some standards are aspirational, others are enforceable guidelines for professional conduct. The Code of Ethics contains standards for social workers in six main areas: 1 . responsibilities to clients, 2 . responsibilities to colleagues, 3 . responsibilities in practice settings, 4. responsibilities as professionals, 5. responsibilities to the social work profession and 6 . responsibilities to society. The new Code was developed by a national committee of social work educators and practitioners appointed by the national NASW Board of Directors. This committee solicited input from professionals 
around the country before the Code was ratified by the NASW Delegate Assembly in August, 1996.

\section{ETHICS AND SOCIAL WORK EDUCATION}

More than forty years ago an early social work educator, Muriel Pumphrey (1959), identified the need to teach students about conflicting values in social work ethics. While ethical dilemmas in supervision have previously been identified (Levy, 1973; Cohen, 1987; Congress, 1992a), ethical challenges for faculty advisors around conflicting duties and responsibilities to school, agency, and student have recently been identified (Congress, 1997). A new area in social work ethics, dual relationships, has been discussed in the context of social work education (Congress, 1996).

The Curriculum Policy statement mandates that social work values and ethics be included in curriculum (CSWE, 1996). How should students learn this content? Should ethics be taught as a discrete course or integrated throughout the curriculum? Research suggests that a discrete course may be more effective in teaching social work students about values and ethics (Joseph, 1991; Joseph and Conrad, 1983; Reamer and Abramson, 1982). A discrete course in ethics can be used to integrate ethics into different areas of required curriculum (Congress, 1993). While in 1989 only $10 \%$ of accredited graduate programs offered a separate required or elective course on ethics (Black, Hartley, Whelley, \& Kirk-Sharp, 1989), recent research suggests that almost half of graduate programs may offer either a required or elective course on ethics (Congress, 1999).

Students may study social work ethics in a separate course or in many courses. Yet much of ethical behavior is learned through observing their teachers (Congress, 1992b; Congress, 1997; Lewis, 1987). Ethical standards "caught" by students may be more significant than what is taught (Lewis, 1987, p. 3). This speaks to the importance of the social work educator not only knowing the Code of Ethics, but also incorporating ethical standards into educational practice.

\section{NEW PROVISIONS IN CODE OF ETHICS}

Preliminary research in this area suggests that even advanced social work practitioners are not that aware of new code provisions (Congress, 1999.) While not exhaustive, the following ten areas focus on new issues in the Code of Ethics:

\section{Limits to confidentiality}

While the earlier Code of Ethics prevented the disclosure of information only for "compelling professional reasons," the new Code of Ethics spells out what these compelling professional reasons are. (NASW, 1993, p. 4; NASW, 1996, p. 10). Social workers are advised to maintain confidentiality, except when it is necessary to prevent serious, foreseeable, and imminent 
harm to a client or other identifiable person. Confidentiality can be breached in reporting child abuse, as the child may be at risk of harm. Also social workers are able to violate confidentiality when a client is suicidal or homicidal. The social worker who suspects child abuse or works with a suicidal client can feel supported by the current Code of Ethics in making a decision to breach confidentiality.

While the 1996 Code originally contained the phrase "when laws or regulations require disclosure without a client's consent" the 1999 Delegate Assembly amended the Code of Ethics to exclude this phrase. There was concern about the growing number of state laws regarding reporting of undocumented people or homosexual couples who want to adopt children. These laws are seen as contrary to our ethical principles that oppose discrimination against people because of legal status or sexual orientation (NASW, 1999).

\section{Confidentiality in technological age}

For the first time, social workers are advised to protect confidentiality in the use of computers, electronic mail, fax machines and telephone answering machines. Disclosure of identifying information should be avoided whenever possible.

While students were previously advised not to leave charts open on their desks when they went to lunch, they now learn to protect confidentiality by computer passwords and firewalls (Rock \& Congress, 1999).

Fax machines present new confidentiality challenges to social workers. Often they are not housed in individual offices, but rather in public office areas where they are accessible to all. Faxed reports are often sent to a fax number with limited knowledge of where they arrive. One social worker recently reported that he frequently received hospital discharge summaries as the number of his home fax machine differed only slightly from that of a large nursing home. Despite the use of passwords, telephone voice mails and e-mail do not protect confidentiality, as they can often be accessed by others.

There are no easy answers. With each new technological advance, confidentiality as we know it is changed forever. To provide for minimal standards of confidentiality in an increasingly less private world, social workers may have to delineate differing degrees of sensitive information and provide differentially for the securing of confidential information. (Rock \& Congress, 1999).

\section{Confidentiality - family and group work}

While previous codes focused primarily on individual work in clients (Dolgoff and Skolnick, 1992; Dolgoff and Skolnick, 1996), the new code 
addresses confidentiality issues in group and family work (NASW, 1996). The inclusion of ethical issues about groups and families is especially relevant as many social workers see clients in groups and families rather than only individually (Ginsberg, 1995). In providing services to groups and families, social workers should seek agreement with all parties about the importance of maintaining confidentiality, but also inform participants that it cannot be guaranteed.

Because other group members as well as family members are usually not professional social workers, the social worker cannot have the expectation that they will maintain confidentiality. Yet the social worker can explain the importance of confidentiality and discuss with the client group or family how the worker will handle confidential information.

\section{Managed care}

While managed care is not cited specifically in the new Code, social workers are advised to inform clients of limits to services because of the requirements of third party payers in sections about informed consent (NASW, 1996, 1.03a, p.7-8) and confidentiality (NASW, 1996, $1.07 \mathrm{~d}$, e, and $f, p .10-11$ ). Although social workers debate about whether managed care threatens client and worker autonomy (Munson, 1996) and confidentiality (Davidson and Davidson, 1996), "managing ethics under managed care" has been seen as possible, although challenging for social workers (Reamer, 1997). Social work practitioners must be alert to when managed care conflicts with social work ethics. Challenges to confidentiality with extensive reporting to managed care companies, as well as limits to service for vulnerable populations, are two main areas of ethical concern. Social work practitioners can be active as client advocates in preserving clients rights in a managed care environment.

\section{Cultural competence}

For the first time, the new Code includes a section on cultural competence and social diversity. Social workers are now expected to understand culture and its function in human behavior with an emphasis on the strengths perspective. Social workers are advised to develop a knowledge base of their clients' culture and demonstrate competence in providing services to people from different cultures. Finally, the current Code mandates social workers to "obtain education about and seek to understand the nature of social diversity and oppression with respect to race, ethnicity, national origin, color, sex, sexual orientation, age, marital status, political belief, religious, and mental or physical disability" (NASW, 1996, p.9). 
A concern about this code provision is how realistic is the expectation that social workers know about all their client cultures, especially in large urban areas with clients from many countries. One social worker who worked in the emergency room of a large public city hospital reported that in the course of the day she had seen clients from twenty different cultural backgrounds. Asking clients about their cultural backgrounds has been seen as a therapeutic and empowering method to use in learning about clients' cultures (Ortiz-Hendricks, 1997).

Another key question is, does learning about characteristics of specific cultures lead to over generalization and stereotyping about cultural characteristics? Self examination is often an important first step in developing cultural and social sensitivity (Aponte, 1991: Ho, 1992; OrtizHendricks, 1997). Also asking clients about specific aspects of their cultural backgrounds and completing a culturagram (Congress, 1994) have been seen as helpful in this area.

\section{Dual relationships}

The current Code of Ethics states that social workers should avoid dual relationships in which there is risk of exploitation or potential harm to clients (NASW, 1996). When the primary relationship is therapeutic, social workers should not enter social, business, or educational relationships with clients. If dual relationships cannot be avoided, the responsibility is on social workers to set appropriate culturally sensitive limits. Dual relationships in agency practice may lead to role reversal (Kagle and Giebelson, 1994), while dual relationships in academia may lead to exploitation of students with limited power (Congress, 1996).

After much debate at the Delegate Assembly, the provision about dual relationships appeared for the first time in the 1993 Code of Ethics. Many social workers, especially in rural areas, indicated that avoiding dual relationships with clients was impossible. In small towns often clients' children went to school with social workers' children. Social workers and their clients often attended the same PTA meetings. Because dual relationships at times cannot be avoided, social workers-not clientsshould assess if the relationship is potentially exploitative or harmful to the client.

While almost all social workers report that sexual relationships with current clients are unethical, they are much less certain about friendship and employment relationships with former clients (Borys and Pope, 1989). Discussing the appropriateness of dual relationships with other colleagues and applying the ETHIC model of decision making can strengthen their skills in deciding when dual relationships are unethical and should be avoided. 


\section{Sexual relationships, physical contact, and sexual harassment}

The current Code has very extensive prohibitions about sexual relationships with clients. While the previous code only addressed the avoidance of sexual relationships with current clients, the new Code forbids sexual contact with former clients, future clients, clients relatives, or close friends.

While almost all practitioners believe that sexual contact with current clients is unethical (Borys and Pope, 1989; Gechtman, 1989), there is less consensus about intimate relationships with former clients (Jayartne, Croxton, \& Mattison, 1997). Social workers are more likely to condone relationships with former clients if the initial contact has been brief, occurred many years ago, and did not involve psychodynamic therapy. The overwhelming majority (95\%) of social work educators believe that sexual contact with current students is unethical, while a much smaller percent $(60 \%)$ in contrast to practitioners believe that sexual contact with former students (clients) is unethical (Congress, 1999).

The current code prohibits social workers from engaging in physical contact with clients when there is possibility of psychological harm. The responsibility rests with the worker to set appropriate boundaries. While the provision about physical contact with clients arose primarily because of concern about sexual abuse of children, the extent of appropriate physical contact with children is often debated.

A prohibition about sexual harassment with clients and colleagues is also included in the current code. Most agencies, as well as schools, have policies about sexual harassment. Despite institutional policies, however, more than half of the graduate social work programs report one or more incidents of sexual harassment (Singer, 1994). Because cases of sexual harassment often become a school or agency secret, the actual incidence of sexual harassment may be much higher.

\section{Impairment and incompetence of colleagues}

While in the previous 1993 Code a social worker who believed a colleague's impairment due to personal problems, psychosocial distress, substance abuse, or mental health difficulties interfered with practice effectiveness was advised to consult with that colleague, the new Code extends that responsibility. If the colleague refuses to address the issue and seek help for the problem, the social worker is now advised to take action through employers, agencies, NASW, licensing, and regulatory bodies. 
Practitioners must assume responsibility for ensuring that social work colleagues not engage in impaired or incompetent practice. Many professional social workers, as well as students, can report occasions on which professional social workers demonstrated poor practice because of substance abuse, burnout, or mental health problems.

At times, substance abuse becomes an agency secret, similar to a family secret about which all know, but rarely speak. Practitioners quite accurately perceive that they have limited power and fear that if they speak to colleagues about substance abuse problems or report impaired behavior to supervisors, then their own occupational progress might be jeopardized. Often NASW can and does provide support to social workers about how to talk with colleagues about substance abuse problems and how to pursue the problem through other channels (Congress and Fewell, 1994).

\section{Application to administrators}

While the earlier NASW Code seemed to apply primarily to direct service practitioners, the new Code includes a section specifically on administration. Social work administrators are advised to advocate for resources in and outside of agencies to meet client needs. They should seek to allocate resources in an open and fair manner. When all clients needs cannot be met, they are required to develop an allocation procedure that is nondiscriminatory. The need to provide adequate staff supervision, as well as a working environment consistent with the Code of Ethics, is also enumerated.

Many direct service practitioners believe that administrators are "above" the Code of Ethics. It is important that practitioners learn that the Code of Ethics applies to administrators who often must struggle with making decisions about the equitable distribution of scant resources (Congress, 1996). Practitioners need to become aware of how ethics affect everyone in an agency (Levy, 1983).

\section{Education and Training}

For the first time the new Code of Ethics specifically addresses issues for educators and trainers. Social work educators are advised to provide instruction only in their areas of competence, and this instruction should be based on the most current knowledge and information. Dual relationships with students should also be avoided when there is a risk of harm or exploitation to the student. An important new Code provision codified an acknowledged field instruction practice, i.e. that social workers should ensure that clients are informed when students provide services (Feiner and Couch, 1985; NASW, 1996). 
In their roles as field instructors, practitioners are required to keep current about social work knowledge and practice skills. This mandate is especially challenging for social work supervisors now with the influx of new knowledge and research in the social sciences. Continuing education for social work supervisors is especially crucial at this time.

\section{ETHICAL DECISION MAKING}

Being informed about the current Code of Ethics, however, is only an initial step for social workers, as frequently they encounter ethical dilemmas in which there is a conflict of social work values and/or ethical principles. As Perlman (1975) has written, a social work value has little value unless it can be translated into ethical practice. Only to know about the Code of Ethics does not make one an ethical practitioner.

How social workers resolve ethical dilemmas has been a subject of some concern to the profession. Social workers are often guided by two main principles. The first beneficence (or positive obligations) speaks to providing good, while the second principle nonmalfeasance (or negative obligations) relates to causing no harm (Reamer, 1995b). Both principles affect ethical decision making. Those who favor beneficence would most likely take a proactive stance, while those favoring nonmalfeasance would favor the least intervention. Social workers acting from a nonmalfeasance perspective might decide to take no action and wait for further results.

Although social workers may not be aware of this, they frequently rely on two philosophical models-deontological and teleological-in resolving ethical dilemmas (Reamer, 1995b). Deontological thinkers believe that social work values such as self determination and confidentiality are so absolute and so definitive of the profession that to deny them would lead to distrust of the professional.

Many social workers, however, use a teleological approach that involves examining the consequences of the situation. Deontologists and teleologists, however, do not always find themselves on opposite sides, as two deontological thinkers might argue about the importance of two contradictory absolute principles such as self determination or the protection of society. In a similar way two teleological thinkers might envision two very different consequences of their decisions.

Most social workers use a combination of deontological and teleological thinking. One can argue that the values of the social work profession are deontological in nature, but often social workers use teleological consequential arguments to decide complex ethical dilemmas. Many social workers do not use a philosophical approach at all, but base their decisions on practice wisdom 
(Walden, Wolock, Demone, 1990) or the Code of Ethics (Congress, 1992). Although there has been a proliferation of books and articles on ethics over the last twenty years, the number of ethical decision making models are few. Lewis (1984) first developed a model of ethical decision making that incorporates both deontological and teleological thinking but proposes that the deontological approach should prevail. Reamer (1995) proposes a deontological system based on Rawls' theory of justice and Gewirth's rank ordering of conflicting duties. Lowenberg and Dolgoff (1996) use a hierarchical model in which different social work values are ranked to help social workers arrive at the best ethical choice.

Social workers, however, frequently make speedy decisions without much deliberation (Wolock, Walden, Wolock, Demone, 1990). This may be related to limited time in which to make decisions, as well as perceived organizational constraints. Moreover, social work practitioners may approach ethical decision making with dread due to fear of making the wrong decision in a litigious environment. There also is anxiety that the process of ethical decision making will require a consideration of very weighty, abstract principles that may seem very removed from practice realities.

In order to make ethical decision making fast and simple and apply to a variety of ethical dilemmas, the ETHIC model of decision making was developed to help social workers make ethical decisions as quickly and as effectively as possible (Congress, 1999a). The following model includes social work values, the Code of Ethics, and the social work context. Based on an easily remembered acronym, the ETHIC model is presented in Table 1 and described more fully below:

\section{TABLE 1. ETHIC Model of Decision Making}

E Examine relevant personal, societal, agency, client and professional values.

T Think about what ethical standard of the NASW code of ethics applies, as well as relevant laws and case decisions.

H Hypothesize about possible consequences of different decisions.

I Identify who will benefit and who will be harmed in view of social work's commitment to the most vulnerable

C Consult with supervisor and colleagues about the most ethical choice. 
Examine relevant personal, societal, agency, client and professional values.

Personal, societal, agency, client and professional values all influence ethical decision making. The social worker who relies only on professional values is not likely to have a full understanding of important contextual issues to use in making decisions. An important initial step for social workers is to assess their own personal values if they want to avoid making decisions based on their personal, rather than professional values. Furthermore, an examination of client values is very important, especially with culturally diverse clients whose values may differ from the personal and professional values of many traditional social workers. An example of this occurred when an Anglo social worker became increasingly aware that she was imposing her personal and professional values about self determination on an adolescent client who based his personal educational objectives on family responsibilities.

A discrepancy between agency and professional values can also produce conflict for the social worker. For example, the social worker supported the professional value of confidentiality, yet in an attempt to promote greater efficiency in handling records the agency had introduced a new computer program with inadequate safeguards to protect confidentiality.

Think about what ethical standard of the NASW code of ethics applies, as well as relevant laws and case decisions.

The ethical standards in the NASW Code of Ethics are divided into six sections:

1. Social workers' ethical responsibilities to clients

2. Social workers' ethical responsibilities to colleagues

3. Social workers' ethical responsibilities to practice settings

4. Social workers' ethical responsibilities as professionals

5. Social workers' ethical responsibilities to the profession

6. Social workers' ethical responsibilities to the broader society.

If the ethical dilemma involves an issue about appropriate treatment for clients, the social worker might want to examine the section under responsibilities to clients. Topics in this section include conflicts of interest, self determination, informed consent, confidentiality, access to records, and issues 
about payment for service and termination of service. The standards can be viewed as deontological (absolute) principles for the social work profession.

Social workers need to be cognizant of relevant federal, state, and local laws that may affect the ethical dilemmas they encounter. Social work ethics is different from, but often parallels, legal regulations. While laws and social work ethics usually coincide, there may be times when they conflict (Thompson, 1990; Dickson, 1995; Dickson, 1998). The social worker needs to be aware when a law or regulation may be unethical. Discriminatory laws about reporting of undocumented people or homosexual couples may be current examples.

\section{Hypothesize about possible consequences of different decisions.}

This step makes use of teleological reasoning to resolve ethical dilemmas. If protecting confidentiality is a concern, the social worker should think about different scenarios, one in which confidentiality is maintained, and the other in which confidentiality is violated. The social worker can list pros and cons about maintaining confidentiality versus breaking confidentiality. Examining possible results helps the social worker decide which is the preferred alternative for the ethical dilemma.

Identify who will benefit and who will be harmed in view of social work's commitment to the most vulnerable

Often social workers must decide between two bad alternatives, rather than one that is clearly right and clearly wrong (Keith-Lucas, 1977). This step may elicit very convincing reasons for or against different courses of action, especially when the Code of Ethics seems to support contradictory decisions.

Social work has had a lengthy tradition of concern for the most vulnerable in our society. The concern for the most vulnerable may distinguish social work from other professions (Lewis, 1972). On a macro level, concern for the most vulnerable has been proposed as a governing principle in regard to downsizing (Reisch \& Taylor, 1983). As the current Code proposes that "social workers should act to expand choice and opportunity for all persons, with special regard for vulnerable, disadvantaged, oppressed, and exploited persons and groups" (NASW, 1996, p 27), this step is most important for social workers in resolving ethical dilemmas.

\section{Consult with supervisor and colleagues about the most ethical choice}

Although often ethical decision making occurs alone, talking to other colleagues who can suggest alternatives or present new information can be very helpful. A social worker who has a supervisor should use this person as a first resource in ethical decision making. With current cutbacks, more experienced 
workers and even beginning workers may have minimal supervision. Social workers are encouraged to bring questions about ethical dilemmas to other colleagues for informal consultation. Sometimes, ethical dilemmas can be presented as part of a case conference and social workers can help the agency develop ethics committees.

The formation of ethics committees may be especially useful in a multidiscipline agency in which the social worker works with other professionals who may not share social work values and ethics (Joseph and Conrad, 1989.) Differences between social workers and doctors (Roberts, 1989) and public school educators (Congress and Lynn, 1994) have been noted. When social workers participate in ethics committees, however, their decisions about ethical dilemmas are often respected by other members (Joseph and Conrad, 1989).

\section{APPLYING THE ETFIC MODEL}

Since the first identification of HIV/AIDS as a very serious, but greatly stigmatized health problem in the early 1980 's, the social work profession has continued to stress the importance of maintaining confidentiality in working with people with AIDS. Preserving confidentiality has been seen as essential to the establishment and continuation of a helping relationship. (Abramson, 1990).

With the spread of AIDS to the heterosexual population and more specifically to those with no known risk behavior, maintaining of confidentiality surrounding AIDS has been questioned. The development of medications that have transformed AIDS from a terminal to chronic illness has also led to the need to know early who is affected even if confidentiality is at risk.

The new Code of Ethics promises confidentiality except when "disclosure is necessary to prevent serious, foreseeable, and imminent harm to a client or other identifiable person" (NASW, 1996, p.10). This principle relates to the Tarasoff Decision in which the courts established a duty to warn an identified victim by stating that "the protective privilege ends when the public peril begins." (Tarasofff 1976: 336-337.) Some have argued that the Tarasoff case is not applicable to the AIDS situation, as often there is not an identifiable victim. Also, violating a client trust may have negative consequences for the client continuing with treatment and/or engaging in safe sexual practices. Others have argued that an HIV-positive individual places an uninformed sexual partner at risk and thus is relevant to the Tarasoff case. The courts as well as ethicists seem to be divided about the correct course of action, but a model of ethical decision making can help the clinician understand more clearly the issues involved and begin to resolve the ethical dilemma of duty to warn with clients who are HIV positive.

The following case example illustrates the application of the ETHIC model in marital therapy when one is HIV-positive. 
Marlene, an experienced MSW, was seeing the Smith family for marital therapy. Their conflicts had increased steadily over their four-year marriage. One of their main stressors was financial (Tom had not been able to work steadily, but occasionally found short term construction jobs, while Joan worked full-time as a cashier at a local grocery store). Another involved their futile attempts to start a family. Both came from a large family and wanted many children, but after trying for four years they still did not have any children. Joan's only pregnancy had ended in a miscarriage at three months. Another area of concern was that Tom was increasingly coming home late from construction jobs after stopping off at a local bar to have a few beers with his friends. One afternoon, Marlene received a frantic call from Tom. Recently he had applied and been accepted for a maintenance job at a local hospital and he was completing routine medical tests needed for employment. His test for HIV antibodies had come back positive. He knew there must be some mistake. He was going to have the test repeated, but he had called Marlene because he just needed to talk to someone. Tom felt that he could not tell his wife as she might leave him. She would be sure to blame him for causing his own illness because he had a three-day drinking binge last year when he disappeared from the house and returned not remembering anything that had happened during this period of time. Tom repeatedly asked Marlene not to tell his wife. He reminded Marlene that he had been promised confidentiality when he first began treatment.

In an attempt to resolve this ethical dilemma, Marlene applied the ETHIC model:

\section{Examine relevant personal, social, agency, client and professional values.}

Marlene began to look very carefully at her own countertransference reactions to people with AIDS. Many social workers have negative attitudes toward people with AIDS. (Ryan \& Rowe, 1988). Marlene realized that although her professional education had taught her otherwise, she felt that a person afflicted with AIDS had almost all the time brought it upon themselves. She thought about homosexuals who were very sexually active, about IV drug users who continued to exchange needles despite the risks. She remembered her family's "black sheep," her second cousin who had been abusing drugs since early adolescence and had died last year of AIDS. She wondered if she blamed 
Tom for not pursuing help with his alcohol problem earlier and thus avoiding his three-day binge and infection with the HIV virus.

In terms of her treatment of this couple, Marlene wondered if she was always more supportive of Joan, as trying harder to make the marriage work. She also thought that her identification and greater support of the wife in a marital couple might be related to her interest in feminist issues.

Marlene knew about negative social values regarding people with AIDS. She acknowledged that her own personal values had been in part shaped by societal tendency to blame the victim. Often, people with AIDS are thought to be responsible for their illness because of their behavior either as a member of a stigmatized population of homosexuals or IV drug abusers. Similar to the worthy and unworthy poor concept, Tom would be considered an unworthy AIDS victim as he "brought the illness on himself," while Joan, if she were to contract the disease, would be viewed as a "worthy" AIDS victim as she caught the disease unknowingly as the wife of an infected person.

What were the agency's values about ADS, about confidentiality? Marlene knew that the mental health agency where she worked did not have any written policies about AIDS, despite a large number of clients who were HIV-positive. She wondered if her agency was similar to many agencies in which not talking about ADS, maintaining it as a secret, was a way of denying its existence. Her agency did have policies about confidentiality. Most of these policies, however, were written about individual clients, despite the fact that increasingly clients were seen in marital, family or group modalities.

What were the client values? Joan realized that as a marital therapist she must understand the values of both her clients. She knew now that Tom seemed to place a high value on confidentiality, perhaps a lesser value on keeping the relationship together. Marlene was less clear about Joan's values about confidentiality, probably because it had never been challenged. She did know that Joan was very committed to maintaining the marriage, no matter what problems the couple had.

Finally, Marlene examined professional values. She knew that the social work profession believed that people with HIV/AIDS were often stigmatized in society. Maintaining confidentiality was seen as an important way to prevent discrimination. Yet she knew that as a professional, she had a responsibility to both clients. Concerned with ethical issues in regard to working with a couple, she had discussed in the beginning how information should be shared with both people, that she would not maintain "secrets" with one member, yet she never anticipated that the secret would be AIDS, about which there was a strong demand to maintain confidentiality. 


\section{Think about which Ethical Standard of the NASW Code of Ethics applies, as well as relevant laws and case decisions.}

Marlene looked carefully at the new Code of Ethics in trying to decide what would be the best course of action. She read about clients" "right to privacy (and protecting) the confidentiality of all information obtained in the course of professional service, except for compelling professional reasons" (NASW, 1996, p. 2). She wondered if protection of Joan and a possible child was a "compelling professional reason" for which "disclosure is necessary to prevent serious, foreseeable, and imminent harm to a client or other identifiable person." (NASW, 1996, p. 2) The state she lived in supported maintaining strict confidentiality about HIV status. Marlene knew there had been some attempts to apply the Tarasoff case in terms of duty to warn to HIV/ADDS cases, but that the results had been mixed.

\section{Hypothesize about different courses of action and possible consequences.}

Marlene tried to think through various courses of action. If she maintained confidentiality, Tom would be pleased. He would continue to come to see her to work with Joan on their marriage. Furthermore, he could receive her support and help in addressing psychological or physical consequences of his HIV/AIDS diagnosis. He could be encouraged to share his health status with his wife at a later time.

On the other hand, there might be serious consequences of not sharing with Joan information about Tom's HIV status. Joan might not be HIV-positive and every day Marlene delayed informing Joan increased the risk of her also being HIV-positive, especially as they were trying to have children. If Joan learned after the fact that Marlene had known about the risk of exposure to AIDS and did not share this information, she could sue Marlene for exposing her to a "clear and imminent danger." Also, by maintaining Tom's confidentiality, Marlene seemed to be promoting Tom's right to confidentiality as more important than Joan's right to well being. When two clients have conflicting positions, Marlene would appear to be siding with one partner, by entering into a collusion around the AIDS secret.

What would be the consequences of violating confidentiality? The best possible scenario is that Joan will be saved from becoming HIV-positive and will be very supportive of Tom. Tom may secretly thank Marlene for telling Joan the secret he could not share. A more negative consequence is that Tom will leave treatment, break up his marriage, or have increasing binges which might increase the possibility of AIDS infection for others. Also, he could charge Marlene with a violation of confidentiality through the NASW Committee on Inquiry, the State Licensing Board, and/or the state court system. 
Identify who will benefit and who will be harmed in view of social work's commitment of the most vulnerable.

If Marlene maintained confidentiality, it would seem that Tom would benefit since his HIV status would remain secret. It can be argued, however, that this would only be time limited. Joan would be harmed in that she would remain uniformed about her exposure to the HIV virus, and furthermore, there is a risk to her anticipated child.

If Marlene decides to tell Joan about Tom's HIV status, Joan will benefit in that she can avoid exposure to HIV virus and also the possibility of giving birth to an HIV infected child. One can anticipate, however, that there may be some harm to Tom in terms of a violation of confidentiality and trust in the therapeutic relationship.

The current Code of Ethics speaks of our professional responsibility to vulnerable people and social work literature has repeatedly addressed the fact that the rights of the most vulnerable should prevail (Lewis, 1972; Reisch and Taylor, 1983). One might argue in the above case example that Joan is the more vulnerable and thus the benefit to her should have greater weight than the benefit to Tom.

Tom and Joan's differing rights are in conflict in this case example. While the principle of confidentiality (Tom's right) is certainly a basic principle in social work practice, the principle of preservation of life (Joan's right) seems more important. While conflicting benefits were in question, a hierarchy of rights such as presented by Lowenberg and Dolgoff (1996) may be helpful.

\section{Consult with supervisor and colleagues about the most ethical choice.}

At lunch Marlene discussed the dilemma with two of her colleagues and received conflicting advice. One social worker believed that Marlene definitely should call up Joan, as she (Marlene) had the power to avoid another person being affected with AIDS. Also, Joan was her client, too. What was her responsibility to protect Joan? Her other colleague was concerned about the violation of confidentiality. How could Tom or for that matter Joan ever trust Marlene again? What was the effect on developing a trusting relationship with a client if confidentiality could be so easily violated? Did not Marlene realize why the social work profession had stressed that knowledge about HIV/AIDS must be treated with the utmost confidentiality? By violating confidentiality, did Marlene increase the possibility of stigma and discrimination against Tom as well as Joan? 
Unlike many graduates with two years experience, Marlene still had the benefit of a supervisor whom she saw regularly. Her supervisor suggested that Marlene think about what she had discussed about confidentiality with her client. Marlene remembered that at the beginning of therapy she had engaged in an extensive discussion about confidentiality with both Tom and Joan. Ironically, Tom had then raised concerns that Joan would be repeatedly calling Marlene with criticisms about him that Joan would not bring up in the joint sessions. They had then made an agreement that whatever was discussed individually would then have to be brought up in the general session and that Marlene as therapist would support and facilitate the process.

Marlene then used the earlier discussion of confidentiality in terms of this new information. She finally encouraged Tom to share with Joan in a joint session about his HIV status and was there to provide continual support for the couple. Ironically, what seemed to be a major stressor-Tom's HIV-positive diagnosis-brought the couple closer together as both Tom and Joan decided to work jointly on coping with this new problem.

The preceeding discussion illustrates the application of the ETHIC model to an ethical dilemma about AIDS and confidentiality. It also demonstrates the importance of establishing confidentiality guidelines early in work with individuals and couples. One can ask if the situation would have been different if Joan had not been a client. Would Marlene have had any responsibility to share HIV status with a nonclient partner? What about nonclient multiple partners? The duty to warn of the Tarasoff decision has not been applied when there are multiple nonspecific victims (Reamer, 1991).

\section{SUMMARY AND IMPLICATIONS}

This paper had two purposes 1 . to inform practitioners and educators about the main new provisions in the current Code of Ethics and 2. to present an easily applicable model of ethical decision making. In recent years, the number of charges about unethical practice of social workers has grown (Reamer, 1996). We are also most aware that we live in an increasingly litigious time. Furthermore, there is greater complexity surrounding ethical issues because of greater use of technology, managed care, and medical advances. As social work educators, we must strive to educate future social workers about how to identify and resolve professional dilemmas. How we as educators model ethical practice with students, however, is equally if not more important than what we teach students didactically about ethics (Lewis, 1987; Congress, 1994).

As practitioners, we must struggle with increasingly complex ethical dilemmas. The ETHIC model provides an easy to apply model in a work environment that is increasingly demanding. The last step of the ETHIC model-Consult with supervisors and colleagues-may be especially important when facing thorny dilemmas. Unfortunately, supervision has decreased even 
for new graduates in the current environment of diminished social service resources.

When there is minimal supervision, both new and experienced social workers must assume primary responsibility for informal consultation with colleagues within and outside the agency. Continuing education programs and NASW can also be resources for professional social workers struggling with complex ethical dilemmas in the new millennium.

\section{REFERENCES}

Abramson, M. (1990), Ethics and technological advances: Contributions of social work practice. Social Work in Health Care, 15(2), 5-17.

Abramson, M. (1990). Keeping secrets: Social workers and AIDS. Social Work, 35(2), 169-173.

Aponte, H. (1991). Training of the person of the therapist for work with the poor and minorities, Journal of Independent Social Work 5(3/4), 23-39.

Beauchamp, T. \& Childress, J. (1996). Principles of biomedical ethics (4th ed.). New York: Oxford Press.

Berman-Rossi, T. \& Rossi, P. (1990). Confidentiality and informed consent in school social work. Social Work in Education, 12(3), 195-207.

Black, P.; Hartley, E.; Whelley, J.; \& Kirk-Sharp, C. (1989). Ethics curricula: A national survey of graduate schools of social work. Social Thought $X V(3 / 4)$, 141-148.

Borys, D. \& Pope, K. (1989). Dual relationships between therapist and client: A national study of psychologists, psychiatrists, and social workers. Professional Psychology: Research and Practice, 20(5), 283-293.

Callahan, J. (1994). The ethics of assisted suicide. Health and Social Work, $19(4), 237-252$.

Cohen, B. (1987). The ethics of social work supervision revisited. Social Work, 32(3), 194-196.

Congress, E. (1992a). Ethical decision making of social work supervisors. The Clinical Supervisor, 10(1), 157-169.

Congress, E. (1992b). Ethical teaching of multicultural students: Reconsideration of social work values for educators. Journal of Multicultural Social Work, 2(2), 11-23.

Congress, E. (1993). Teaching ethical decision making to a diverse community of students: Bringing practice into the classroom. Joumal of Teaching in Social Work, 7(2), 23-36.

Congress, E. (1994). The use of the culturagram to assess and empower culturally diverse families. Families in Society, 75, 531-540.

Congress, E. (1996). Dual relationships in academia: Dilemmas for social work educators. Journal of Social Work Education, 32(3), 329-338.

Congress, E. (1997). Value dilemmas of faculty advising: Significant issues in a Code of Ethics for faculty advisors. Journal of Teaching in Social Work, 14(2), 89-110. 
Congress, E. (1999a). Social work values and ethics: Identifying and resolving professional dilemmas. Chicago: Nelson Hall.

Congress, E. (1999b). Dual relationships in academia. Unpublished research study.

Congress, E. \& Fewell, C. (February/March, 1994). Recognizing substance abuse in a colleague: What can I do? What should I do? Currents. New York: NASW.

Congress, E. \& Gummer, B. (1996). Is the Code of Ethics as applicable to agency administrators as direct service providers. In $\mathrm{E}$. Gambril and $\mathrm{R}$. Pruger, Controversial issues in social work ethics, values, and obligations (pp.137-150.) Boston: Allyn Bacon.

Congress, E. \& Lynn, M. (1994). Group work programs in public schools: Ethical dilemmas and cultural diversity. Social Work in Education, 16(2), 107-114.

Congress, E. \& Lynn, M. ( 1997). Group work practice in the community: Navigating the slippery slope of ethical dilemmas. Social Work with Groups 20(3), 61-74.

Congress, E. \& Lyons, B. (1992). Cultural differences in health beliefs: Implications for social work practice in health care settings. Social Work in Health Care, 17(3), 81-96.

Council of Social Work Education. (1996). Curriculum Policy Statement. Alexandria, VA: Author.

Davidson, J. \& Davidson, T. (1996). Confidentiality and managed care: Ethical and legal concerns. Health and Social Work, 21(3), 208-215.

Dickson, D. (1995). Law in the health and human services. New York: The Free Press.

Dickson, D. (1998). Confidentiality and privacy in social work. New York: The Free Press.

Dolgoff, R. \& Skolnik, L. (1992). Ethical decision making, the NASW Code of Ethics and group work practice: Beginning explorations. Social Work with Groups, 15, 99-112.

Dolgoff, R. \& Skolnik, L. (1996). Ethical decision making in social work with groups. Social Work with Groups, 19,(2), 49-65

Feiner, H. \& Couch, E. (1985). I've got a secret: The student in the agency. Social Casework, 66(5), 268-274.

Garrett, K. (1994), Caught in a bind: Ethical decision making in schools. Social Work in Education 16, 2, 97-106.

Gechtman, L. (1989). Sexual contact between social workers and their clients. In G. Gabbard (ed.), Sexual exploitation in professional relationships (pp. 27-38). Washington, DC: American Psychiatric Press.

Ginsberg, L. (1995). Social work almanac. Washington, DC: NASW Press.

Ho, M. (1991). The use of the ethnic sensitive inventory (ESI) to enhance practitioner skills with minorities. Journal of Multicultural Social Work, (1), 57-68.

Houston-Vega, M., Nuehring, E.; \& Daguio, E.(1997). Prudent practice: A guide for managing malpractice risk. Washington, DC: NASW Press. 
Jayaratne, S; Croxton, T. \& Mattison, D. (1997). Social work professional standards: An exploratory study, Social Work, 42(2), 187-199.

Joseph, V. (1983). The ethics of organizations: Shifting values and ethical dilemmas. Administration in Social Work, 7(3/4), 47-57.

Joseph, V. (1991). Standing for values and ethical action: Teaching social work ethics. Journal of Social Work Education, S(2), 95-109.

Joseph, V. \& Conrad, A. (1989). Social work influence on interdisciplinary decision making in health care settings. Health and Social Work, 14(1), 2230.

Kagle, J. \& Giebelhausen, P. (1994). Dual relationships and professional boundaries. Social Work, 31(2), 213-220.

Kagle, J. \& Kopels, S. (1994). Confidentiality after Tarasoff. Health and Social Work, 19(3), 217-222.

Keith-Lucas, A. (1977). Ethics in social work. In Encyclopedia of Social Work 17th Ed. (pp. 350-355). Washington, DC: NASW.

Levy, C. (1973). The ethics of supervision. Social Work, 18(3), 14-21.

Levy, C. (1983). Guide to ethical decisions and actions for social service administrators: A handbook for managerial personnel. New York: Haworth Press.

Lewis, H. (1972). Morality and the politics of practice. Social Casework, 5(3), 404-417.

Lewis, H. (1984). Ethical assessment. Social Casework, 65(4), 203-211.

Lewis, H. (1987). Teaching ethics through ethical teaching. Joumal of Teaching in Social Work, 1(1), 3-14.

Lowenberg, F. \& Dolgoff, R. (1996). Ethical decisions in social work practice. Itasca, Ill: Peacock Publishing.

Munson, C. (1996). Autonomy and managed care in clinical social work practice. Smith College Studies in Social Work, 66(3), 241-259.

National Association of Social Workers (1960). Code of ethics. New York: NASW

National Association of Social Workers (1993). Code of ethics. Washington, DC: NASW.

National Association of Social Workers. (1996). Code of ethics. Washington, DC: NASW.

National Association of Social Workers. (1999, November 1999). Ethics and Reporting Eyed after Assembly. NASW NEWS, p. 5.

Ortiz Hendricks, C. (1997). The child, the family, and the school: A multicultural triangle. In E. Congress, Multicultural perspectives in working with families. (pp. 37-60). New York: Springer Publishing.

Perlman, H.(1975). Self determination: Reality or illusion? In. F. McDermott (Ed.), Self determination in social work. (pp. 65-89). London: Routledge and Paul Kegan.

Pine, B. (1987). Strategies for more ethical decision making in child welfare practice. Child Welfare, 66(4), 315-326.

Proctor, E; Morrow-Howell, N. \& Lott, C. (1993). Classification and correlates of ethical dilemmas in hospital social work. Social Work, 38(2), 166-177. 
Pumphrey, M. (1959). Teaching of values and ethics in social work education. New York: Council of Social Work Education.

Reamer, F. (1991). AIDS: The relevance of ethics. In F. Reamer, AIDS and ethics. (pp. 1-25). New York: Columbia University Press.

Reamer, F. (1994). Social work malpractice and liability: Strategies for prevention. New York: Columbia University Press.

Reamer, F. (1995a). Malpractice claims against social workers: First facts. Social Work, 40(5), 595-601.

Reamer, F. (1995b). Social work values and ethics. New York: Columbia University Press.

Reamer, F. (1997). Managing ethics under managed care. Families in Society, 96-106.

Reamer, F. (1998). Ethical standards in social work: A critical review of the NASW Code of Ethics. Washington D.C.: NASW Press.

Reamer, F. (1998). The evolution of social work ethics. Social Work, 43(6), 488-500.

Reamer, F. \& Abramson, M. (1982).The teaching of ethics XI: The teaching of social work ethics. Hastings on the Hudson, NY: The Hastings Center.

Rhodes, M. (1991). Ethical dilemmas in social work practice. Milwaukee, WI: Family Service America.

Reisch, M. \& Taylor, C. (1983). Ethical guidelines for cutback management: A preliminary approach. Administration in Social Work, $7(3 / 4), .59-72$.

Roberts, C. (1989). Conflicting professional values in social work and medicine. Health and Social Work, 14(3), 211-218.

Rock, B. \& Congress, E. (1999). The new confidentiality for the 21 st century in an managed care environment. Social Work, 44(3), 253-262.

Singer, T.(1994). Sexual harassment in graduate schools of social work: Provocative dilemmas. In M. Weil, M. Hughes, and N. Hooyman, Sexual harassment and schools of social work: Issues, costs, and strategic responses (pp. 25-37). Alexandria, VA: Council on Social Work Education.

Tarasoff v. Board of Regents of University of California (1976). $17 \mathrm{Cal} 3 \mathrm{~d}$ 425. Thompson, R. (1990). Ethical dilemmas in psychotherapy. New York: The Free Press.

Walden, T., Wolock, I. \& Demone, H. (1990). Ethical decision making in human services. Families in Society, 71(2), 67-75.

Address correspondence to: Elaine Congress, DSW, Professor and Director of the Doctoral Program, Fordham University Graduate School of Social Service, 113 West $^{\text {th }}{ }^{\text {th }}$ Street, New York, NY 10021, (212)636-6627, congress@fordham.edu 


\section{INSTRUCTIONS TO EARN CEU CREDITS}

To earn CEU credits for reading this article:

A. Complete the following test. Use a photocopy of test.

2 credits

B. Write (i) a critical review of the article and (ii) a detailed explanation of how you will be able to use the information contained in the article in your professional activity.

2 credits

C. Discuss the relevance of the content of the article to human services generally. Discuss your professional experience in dealing with ethical dilemmas and the method(s) you used in resolving them.

2 credits

Each essay must be between 350 to 400 words and double-spaced typed. Send the completed test and essays along with fees $@ \$ 5.00$ per credit by check payable to Indiana University School of Social Work to:

Editor, Advances in Social Work

Indiana University School of Social Work

902 West New York Street

Indianapolis, IN 46202-5156

The School of Social Work will notify you as to whether you have satisfactorily met the requirements for a $6 \mathrm{CEU}$ credits or less for this article. For questions regarding the CEU credits, contact by phone or mail:

Editor, Advances in Social Work

Indiana University School of Social Work

902 West New York Street

Indianapolis, IN $46202-5156$

Telephone: (317) 274-6705

Fax:

(317) $274-8630$

E-mail: editor@iupui.edu

NOTE: The readers should contact their state licensing/certificate agency for eligibility of earning CEU credit from the Indiana University School of Social Work and the procedure for obtaining approval in their state. 


\section{CEU TEST}

1. According to Reamer over the years the focus of ethics has shifted from a concern with the of the to the of the

2. Name two anthors of books about social work ethics.

3. The first NASW Code of Ethics in was 1 page and contained 14 statements, while the current Code adopted in is 27 pages with 155 provisions.

4. Some of the standards delineated in the current Code are , while others are guidelines for professional conduct.

5. The NASW Code delineates ethical responsibilities in the following areas:

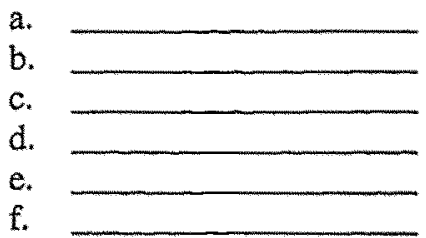

6. the first social work educator to focus on social work ethics identified the need to teach students about conflicting values in social work ethics.

7. The of requires the inclusion of content on values and ethics.

8. Ethical conduct that students observe may be more significant than what they are taught.

True or False

9. Under what circumstances does the NASW Code of Ethics permit breaching confidentiality?

10. There are special challenges to confidentiality in an era.

11. While previously the Code addressed confidentiality only in terms of work with clients, the current Code looks at confidentiality with 

and

12. Managed care is specifically addressed in the current Code of Ethics. True or False

13. Cited for the first time in the current Code, the provision about requires social workers to become familiar with the of their clients.

14. Social workers are mandated to avoid dual relationships with or clients when there is risk of or

15. While social workers agree that dual relationships of a nature with current clients is unethical, they are more divided about whether dual relationships of a or nature should be avoided.

16. When a social worker has a colleague whose behavior is impaired because of substance abuse, what is the first step a social worker should take?

17. The current Code of Ethics for the first time speaks specifically about social workers who function as or

18. Most social workers use a specific detailed model of ethical decision making. True or False

19. Congress's ETHIC model includes the following five steps:

1.

2.

3.

4.

5.

20. Maintaining ___ in working with people with has been seen as particularly challenging. 


\section{Why pick Indiana University to earn an MSW?}

The IUSSW offers an accredited MSW Program with a variety of options. This 60 credit hour degree can be obtained on a full time, parttime and advanced standing basis. The program offers interpersonal as well as MACRO practice concentrations.

Students entering the MSW program at Indianapolis are fortunate to attend a located in the the United Indianapolis walking distance capital, which direct access to of the state.

Indiana

Medical School,

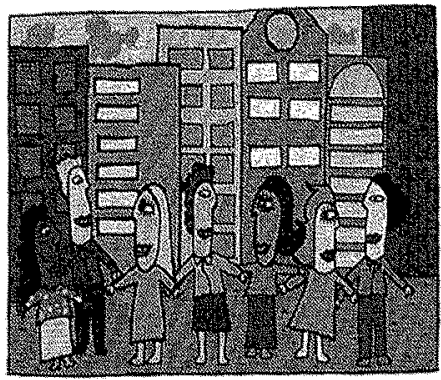
University that is $12^{\text {th }}$ largest city in States. The campus is within of the State allows students the policy makers Furthermore, the University Riley Hospital for Children, and four other major medical centers are located in the area and offer students a wide variety of learning experiences in the medical field.

Due to the long-standing history of Indiana University School of Social Work, there is a large network of agencies available for a student to participate in practica that offer a wide range of settings. The location of the School also offers students practicum experiences in urban and rural areas.

For additional information about the MSW Program, contact Sherry Gass, MSW Admissions and Student Services Coordinator at sgass@iussw.iupui.edu. To request an application, contact the school at $317-274-6705$

Visit our web site at: http://iusswiupui.edu

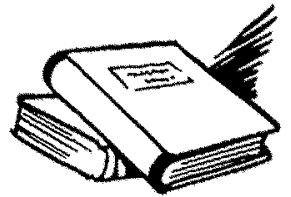

